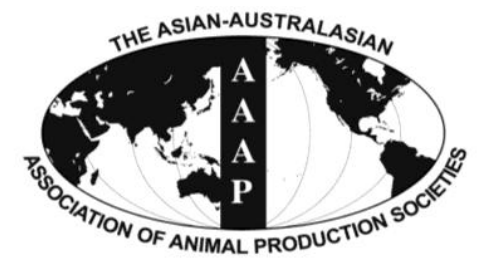

Asian Australas. J. Anim. Sci.

Vol. 26, No. 6 : 896-904 June 2013

http://dx.doi.org/10.5713/ajas.2012.12677

Www.ajas.info

pISSN $1011-2367$ elSSN 1976-5517

\title{
Effect of Cattle Breeds on Milk Composition and Technological Characteristics in China
}

\author{
T. X. Yang, H. Li, F. Wang, X. L. Liu and Q. Y. Li* \\ College of Light Industry and Food Engineering, Guangxi University, 100 Daxue Road, Nanning 530004, China
}

\begin{abstract}
Cattle breeds have a striking effect on milk, including milk composition and technological characteristics. This study aims to compare milk composition, acidification activity, viscosity, milk dispersion system stability and casein molecular weight among three buffalo breeds in China. The technological characteristics of milk produced by three cattle breeds of river buffalo (Murrah), crossbreed 1st generation $\left(\mathrm{F}_{1}\right)$, crossbreed multiple generation $\left(\mathrm{F}_{\mathrm{H}}, \mathrm{H} \geq 3\right)$ buffaloes were investigated. Cattle breeds showed evident effect on milk protein, fat and total solids content, but little effect on most of buffalo casein molecular weight. Milk fat, protein content and the viscosity of buffalo milk from river buffalo were lower than those of $F_{1}$ and $F_{H}$, so was the buffer capacity. The viscosity was negatively correlated to temperature and concentration. Results of stability coefficient showed that milk dispersion system had the best dynamic stability characteristics under $\mathrm{pH} 6.6$ and 6 times dilution, while zeta potential of Murrah milk was slightly higher than that of hybrid offspring $\left(\mathrm{F}_{1}, \mathrm{~F}_{\mathrm{H}}\right)$. SDS-PAGE results showed that buffalo $\alpha_{\mathrm{s}}$-casein had a slightly faster mobility than standard $\alpha_{\mathrm{s}}$-casein; while buffalo $\beta$-casein showed a slightly slower mobility than standard $\beta$-casein. There is no clear differences in molecular weight of $\alpha_{\mathrm{s}}$-, $\beta$-, and $\kappa$-casein among Murrah, $\mathrm{F}_{1}$ and $\mathrm{F}_{\mathrm{H}}$. (Key Words: Cattle Breed, Buffalo Milk, Buffer Capacity, Rheological Property, Zeta Potential)
\end{abstract}

\section{INTRODUCTION}

Cattle breeds have a striking effect on meat and fat color, muscle structure and meat physiology (Waritthitham et al., 2010; Xie et al., 2012), as well as their product (milk). Because of genetic background, milk from different cattle breeds holds distinct composition profiles (Poulsen et al., 2012). The nutritional value of buffalo milk was higher than that of Holstein cow milk (Lindmark-Månsson et al., 2003; Benincasa et al., 2008; Maurice-Van Eijndhoven et al., 2011). Buffalo breeds contain swamp buffaloes and river buffaloes, which accounted for $67 \%$ and $33 \%$ respectively. Swamp buffaloes (karyotype $2 n=48$ ) are draft animals and have low performance in milk production (milk yield, $~ 700$ kg per cow per annum), but high total solids (Ts) content; river buffaloes (karyotype $2 \mathrm{n}=50$ ), as represented by Murrah buffalo, have a good milk yield $(\sim 2,200 \mathrm{~kg}$ per cow per annum), but lower Ts content compared with swamp buffaloes (Han and Ding, 1994). Most of the swamp buffaloes are distributed throughout south China. In order to improve the quality and yield of local buffalo (swamp

\footnotetext{
* Corresponding Author: Q. Y. Li. Tel: +86-136-678-83719, Fax: +86-0771-3232874, E-mail: liquanyang@163.com Submitted Dec. 7, 2012; Accepted Feb. 28, 2013; Revised Mar. 6, 2013
}

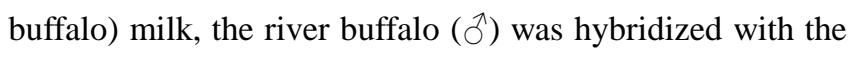
local swamp buffalo ( $($ ). The hybrid offspring buffaloes produce milk with a higher content of dry matter compared with the milk from river buffalo (Han et al., 2007). In recent years, buffaloes have been rapidly developed as milk producer, and the yield of hybrid buffalo milk increases substantially in China (Pang et al., 2007).

The technological characteristics of milk closely relate to the texture and stability of dairy products based on the milk composition. They are affected by temperature (Jeurnink and Kruif, 1993), concentration, and $\mathrm{pH}$ value among other factors (Ahmad et al., 2008; Ménard et al., 2010). Although a great deal of work has been done on the physic-chemical properties of cow milk, even on some of the physic-chemical properties of buffalo (Bubalus bubalis) milk (Jeurnink and Kruif, 1993; Anema and Klostermeyer, 1996; Ahmad et al., 2008; Ménard et al., 2010), and the effects of feeding and management of cattle on milk composition have also been explored by a number of researchers (Maurice-Van Eijndhoven et al., 2011; Norrapoke et al., 2012; Terramoccia et al., 2012), little is known about the technological characteristics of milk from different buffalo breeds. Moreover, the technological properties and chemical composition of crossbreed buffalo milk remains unclear. 
Because of the known general milk composition (Han and Ding, 1994) and the lower milk yield, the technological properties of local swamp buffalo will not be considered in this work. Therefore, in order to get more information about the technological properties of milk from different buffalo breeds to produce the suitable dairy products, this study was carried out to evaluate the technological properties and the main differences in composition among three local buffalo breeds in China, which were Murrah buffalo (river buffalo), crossbreed offspring (river buffalo ${ }^{\lambda} \times$ swamp buffalo $\bigcirc$ ) 1 st generation buffalo $\left(\mathrm{F}_{1}\right)$, and crossbreed multiple generation buffalo $\left(\mathrm{F}_{\mathrm{H}}, \mathrm{H} \geq 3\right)$ that was produced by breeding with river buffalo as shown in Figure 1.

\section{MATERIALS AND METHODS}

\section{Milk samples}

Fresh whole milk samples from Murrah (river buffalo), crossbreed (river buffalo $\partial^{\lambda} \times$ swamp buffalo $q$ ) 1 st generation $\left(F_{1}\right)$, and crossbreed multiple generation $\left(F_{H}\right)$ buffaloes were collected in Wutang farm (indoors) of Nanning, Guangxi, China. Total of 108 milk samples (36 from each breed) were collected. 108 buffaloes were fed a total mixed rations (TMR) with a forage/concentrate ratio of $70 / 30$. The diet consisted of grassiness (35\%), maize stalk silage $(35 \%)$, and concentrate $(30 \%)$ made from maize $(45 \%)$, soybean pomace $(20 \%)$, wheat bran $(15 \%)$, cottonseed meal $(10 \%)$, by-products such as brewers dried grain $(5 \mathrm{~kg}$ per cow per day), and salt and mineral elements (10\%). The diet was provided by Dr. Wei from Wutang farm, Nanning, Guangxi, China. Management practices were applied equally to all buffaloes. Standards of $\alpha$-casein $(\alpha-\mathrm{CN}), \beta$-casein $(\beta-\mathrm{CN})$, and $\kappa$-casein $(\kappa-\mathrm{CN})$ were from Sigma (Sigma-Aldrich [Shanghai] Trading Co., Ltd. Shanghai, China). Holstein cow casein provided by our laboratory was used as a reference. Molecular weight marker 10 to $200 \mathrm{kDa}$ (\#SM0661) was obtained from Fermentas (USA). Other reagents were all of analytical grade.

\section{General composition}

Milk fat and crude protein content were determined by the Babcock and Kjeldahl methods, respectively. Lactose was determined by colorimetric method according to the Chinese standard method (GB/T 16285-1996). Ts were determined by conventional ovendrying $\left(60^{\circ} \mathrm{C}\right.$ for 2 to $3 \mathrm{~h}$, then $100^{\circ} \mathrm{C}$ for $6 \mathrm{~h}$ ) of $5 \mathrm{~g}$ milk sample. The $\mathrm{pH}$ was measured using a Microcomputer $\mathrm{pH}$ meter (Sartorius Instruments, Germany); calibration was done with buffers of $\mathrm{pH} 4.00$ and $\mathrm{pH} 6.80$.

\section{Buffer capacity}

The buffering capacity was measured according to Van Slyke with some modifications (Slyke, 1922). Briefly, 100

\author{
river buffalo (male) $X$ swamp buffalo (female) \\ $\downarrow$

Figure 1. Crossbreed multiple generation $\left(\mathrm{F}_{\mathrm{H}}\right)$ buffalo was produced by breeding with river buffalo, $\mathrm{H} \geq 3$.

$\mathrm{ml}$ milk were slowly added with $0.1 \mathrm{M} \mathrm{HCl}$ or $0.1 \mathrm{M} \mathrm{NaOH}$ under vigorous stirring at room temperature $\left(25 \pm 1^{\circ} \mathrm{C}\right)$. All the experiments were carried out in duplicate.

\section{Stability coefficient}

One ml of each milk sample was 1:20 diluted with Milli Q-water at room temperature and divided into two parts. For one part, the $\mathrm{pH}$ values were adjusted from $\mathrm{pH} 4.2$ to pH 7.0 with $0.2 \mathrm{M}$ phosphate buffer, the other part was diluted 2 to 8 times again, and proper amount of samples was centrifuged at $1,420 \mathrm{~g}$ for $5 \mathrm{~min}$. The absorbance of all samples was measured at $780 \mathrm{~nm}$ using an ultraviolet spectrophotometer (1601 ultraviolet spectrophotometer, Shimadzu).

\section{Viscosity measurements}

Viscosity measurements were performed using an Ostwald capillary viscometer (Shanghai Liangjing, China) by the method of Jeurnink and de Kruif (Jeurnink and Kruif, 1993) with slight modification. One part of sample was measured at various temperatures from 4 to $95^{\circ} \mathrm{C}$, the other part was diluted 2 to 8 times and measured at room temperature. Samples were equilibrated in a temperaturecontrolled thermostat water bath for 30 min before viscosity measurements at each temperature.

\section{Zeta potential measurements}

Zeta potentials (the net charge on a particle, in $\mathrm{mV}$ ) were measured by laser Doppler electrophoresis with the Nano-S Zetasizer (Malvern Instruments Limited, Malvern, Worcestershire, UK). Samples were measured under various $\mathrm{pH}$ (from 4.5 to 7.0 ) and dilution ratio (all milk samples were diluted 2, 4, 6, 8 times again with Milli Q-water) after dilution for 200 times with Milli Q-water as described previously (Liu et al., 2011).

\section{Gel electrophoresis analysis}

Sodium dodecyl sulfate polyacrylamide gel electrophoresis (SDS-PAGE) of the samples was carried out on a Bia-Rad System (Mini-Protean 3 cell, USA) as described previously (Laemmli, 1970). The protein samples 
Table 1. Chemical composition of samples

\begin{tabular}{lcccccc}
\hline Sample & $\begin{array}{c}\text { Fat } \\
(\% \mathrm{v} / \mathrm{v})\end{array}$ & $\begin{array}{c}\text { Protein } \\
(\% \mathrm{w} / \mathrm{w})\end{array}$ & $\begin{array}{c}\text { Ts } \\
(\% \mathrm{w} / \mathrm{w})\end{array}$ & $\begin{array}{c}\text { NFS } \\
(\% \mathrm{w} / \mathrm{w})\end{array}$ & $\begin{array}{c}\text { Lactose } \\
(\% \mathrm{w} / \mathrm{w})\end{array}$ & $\mathrm{pH}$ \\
\hline Murrah $(\mathrm{n}=36)$ & $6.65 \pm 0.08^{\mathrm{b}}$ & $4.65 \pm 0.05^{\mathrm{b}}$ & $17.23 \pm 0.7^{\mathrm{b}}$ & $10.31 \pm 0.19^{\mathrm{a}}$ & $5.11 \pm 0.16^{\mathrm{ab}}$ & $6.61 \pm 0.04^{\mathrm{ab}}$ \\
$\mathrm{F}_{\mathrm{H}}(\mathrm{n}=36)$ & $8.16 \pm 1.11^{\mathrm{a}}$ & $4.96 \pm 0.03^{\mathrm{a}}$ & $18.58 \pm 1.07^{\mathrm{a}}$ & $10.33 \pm 0.41^{\mathrm{a}}$ & $5.05 \pm 0.10^{\mathrm{ab}}$ & $6.45 \pm 0.04^{\mathrm{c}}$ \\
$\mathrm{F}_{1}(\mathrm{n}=36)$ & $8.46 \pm 0.26^{\mathrm{a}}$ & $5.13 \pm 0.15^{\mathrm{a}}$ & $19.51 \pm 0.35^{\mathrm{a}}$ & $10.91 \pm 0.13^{\mathrm{a}}$ & $5.27 \pm 0.18^{\mathrm{a}}$ & $6.48 \pm 0.14^{\mathrm{bc}}$ \\
\hline
\end{tabular}

$\mathrm{n}=$ Number of samples; Ts = Total solids content; NFS = Non-fat content; $\mathrm{M}=$ Murrah buffalo (river buffalo) milk.

$\mathrm{F}_{1}, \mathrm{~F}_{\mathrm{H}}=$ Crossbreed buffalo (river buffalo ${ }^{\lambda} \times$ swamp buffalo + ) 1 st generation, crossbreed multiply generation buffalo milk, respectively.

${ }^{a b c}$ Means bearing different superscripts in the same column differ significantly $(\mathrm{p}<0.05)$.

* Means \pm SD.

were solubilized with phosphate buffer after ultracentrifugation at appropriate concentrations at $20^{\circ} \mathrm{C}$. Gel was stained with Coomassie blue dye for $2 \mathrm{~h}$, followed by destaining in a solution containing $30 \%$ methanol and $10 \%$ acetic acid.

\section{Statistical analysis}

All data were analyzed by one-way ANOVA using the statistical analysis software (SPSS Statistics 17.0, 2010). Differences with $\mathrm{p}<0.05$ were considered statistically significant.

\section{RESULTS AND DISCUSSION}

\section{General composition}

The general composition of three types of milk were significantly different $(\mathrm{p}<0.05)$ among the three cattle breeds under the same feeding condition (Table 1). Ts content of swamp buffalo (22.64\%, w/w; Han and Ding, 1994) was higher than that of river buffalo $(17.23 \%$, w/w) and their hybrid offspring $(19.05 \%, \mathrm{w} / \mathrm{w})$. The milk yield of local swamp buffalo was low ( $700 \mathrm{~kg}$ per cow per annum), but the Ts content was high; on the contrary, Murrah showed the high milk yield ( 2,200 kg per cow per annum) and low Ts content. In the current study, it is important to note that the milk yield of crossbreed offspring $\left(\mathrm{F}_{1}, \sim 1,500\right.$ $\mathrm{kg}$ per cow per annum; $\mathrm{F}_{\mathrm{H}}, \sim 2,100 \mathrm{~kg}$ per cow per annum) was higher than that of the swamp buffalo (female parent), and the milk compositions including fat, protein and Ts contents of crossbreed offspring $\left(\mathrm{F}_{1}\right.$ and $\left.\mathrm{F}_{\mathrm{H}}\right)$ were higher than those of Murrah (male parent), and all above composition contents of $F_{1}$ were higher than those of $F_{H}$. There was no great difference between crossbreed offspring milks, but $\mathrm{F}_{1}$ milk was $5.71 \%$ higher than the other buffalo milk, indicating that $F_{1}$ buffalo milk had the highest nutritive value. Fat, protein, and Ts contents of $\mathrm{F}_{\mathrm{H}}$ milk were $22.71 \%, 6.67 \%$, and $7.84 \%$ respectively higher than those of Murrah. This also inferred that the more the multigenerations, the closer the main milk composition to their male parent's.

\section{Buffer capacity of three cattle breeds}

The acidification of milk from different buffalo breeds was studied by ANOVA. Nevertheless, the buffer capacity of the river buffalo milk was higher than that of the hybrid offspring buffalo milk ( $\mathrm{p}<0.05)$, and the buffer capacity of $F_{1}$ milk was slightly higher than that of $F_{H}$ milk (Figure 2). The milk protein contents of the three local breeds were

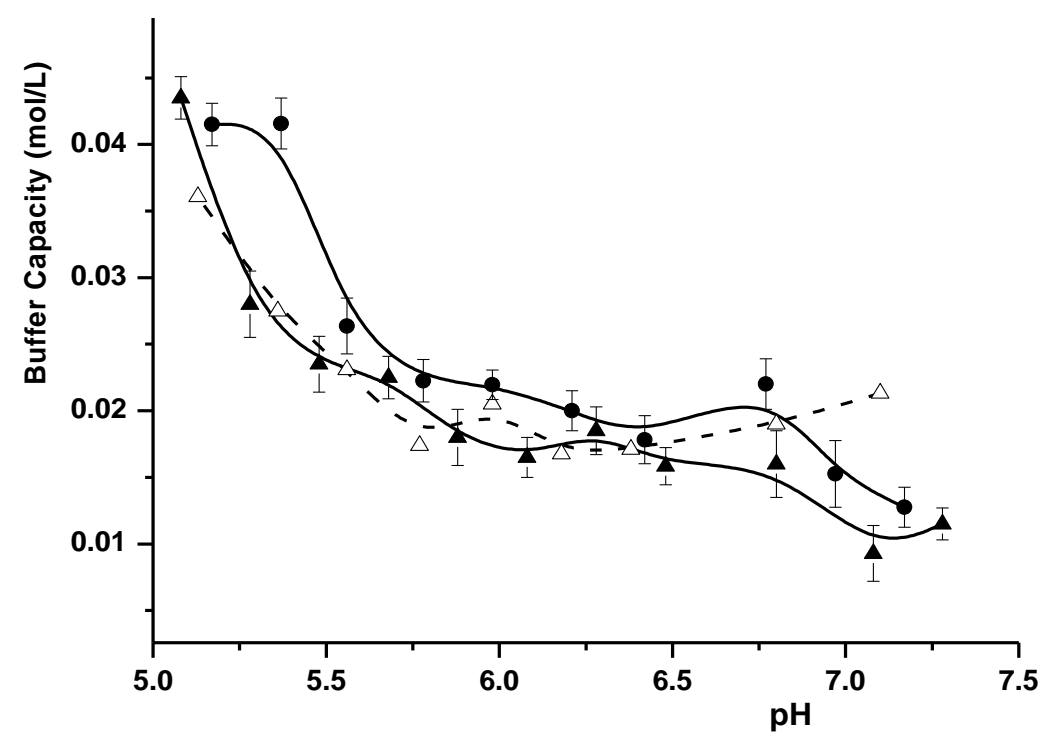

Figure 2. Buffer capacity of acidified milk samples from initial $\mathrm{pH}$ to $\mathrm{pH} 5.0$ with $\mathrm{HCl}(0.1 \mathrm{M})$. Symbols: $\bullet, \mathrm{Murrah} ; \Delta, \mathrm{F}_{1} ; \boldsymbol{\Delta}, \mathrm{F}_{\mathrm{H}}$. 
ranked as follows: $F_{1}>F_{H}>$ Murrah (Table 1). The different buffer capacities were probably related to the higher casein content in buffalo milk same as the buffer properties of milk. It demonstrated that there were no clear correlation between milk protein content and buffer capacity. The buffer capacity of milks might also relate to their composition of acido-basic compounds, calcium phosphate, and phosphorylation of casein (Salaün et al., 2005). Moreover, the protein content and molecular organization also plays an important role in buffering capacity, e.g., inorganic phosphate contributes to the buffering capacity too (Ahmad et al., 2008). These results indicated that $F_{1}$ had a better buffer capacity with much more buffering components, such as higher contents of protein, Ts, as well as inorganic phosphate.

\section{Effect of concentration and pH of three cattle breeds on milk stability coefficient}

Stability is an important attribute of dairy products. The stability coefficient $(\mathrm{R})$ of samples was determined under different $\mathrm{pH}$ and dilutions (Figures 3 and 4).

$\mathrm{R}$ values of the three types of milk were high under natural $\mathrm{pH}$ ranging from 6.45 to 6.63. As shown in Figure 3, $\mathrm{R}$ values of all milk samples increased with the increasing $\mathrm{pH}$ value, and the maximum $\mathrm{R}$ value of Murrah and $\mathrm{F}_{1}$ milk appeared at $\mathrm{pH}$ 6.6; however, the $\mathrm{R}$ of $\mathrm{F}_{\mathrm{H}}$ reached maximum at $\mathrm{pH} 6.2$ and was lower at $\mathrm{pH}$ 6.6, which was significantly different from that of other breeds. There were no evident differences in $R$ values between Murrah and $F_{1}$. These results indicated that the nuclear charge number of casein micelle of Murrah milk was similar to that of $F_{1}$ near their natural $\mathrm{pH}$ value.

As the milk was acidified, the nuclear charge number of casein micelle changed gradually, and the hydration reduced slowly, but the interaction of sub-microsphere became weak. The aggregation of loosely entangled proteins was observed, which were presumably originated from proteins that dissociated from the casein micelles. These aggregates became larger with the decreased $\mathrm{pH}$ value and precipitated rapidly, particularly when the $\mathrm{pH}$ approached the isoelectric point of caseins. The $\mathrm{R}$ values of milk of all breeds decreased with the increasing $\mathrm{pH}$ from 4.2 to 5.0, and reached the minimum value at $\mathrm{pH} 5.0$ except of that of Murrah milk, which was higher at $\mathrm{pH} 5.0$ and reached the minimum at $\mathrm{pH}$ 5.4. The differences in minimum $\mathrm{R}$ values were not evident among all kinds of milk. It suggests that the hydrophobic interactions between proteins, casein dephosphorylation, and reassociation of proteins, destabilized the colloid system (McMahon and Oommen, 2008; McMahon et al., 2009; Kehoe and Foegeding, 2011), and all breeds of milk dispersion systems exhibited instability around pH 5.0. McMahon et al. (2009) reported the occurrence of acid gelation of milk at $\mathrm{pH}$ between 5.3 and 4.9, which involved a reassociation of loosely entangled protein aggregates into more-compact colloidal particles or association with any remaining casein supramolecules. However, this study found that the specific conditions for three types of milk were different.

$\mathrm{R}$ of milk varied as a function of dilution factor (Figure 4). It decreased with the increasing dilution ratio in the initial stage and then increased. The $\mathrm{R}$ values of Murrah, $\mathrm{F}_{1}$, and $F_{H}$ reached the peaks at 6 times diluted, suggesting that the dispersion system achieved a relatively stable state. There were no significant differences among all milk samples. Yet, the correlation between $\mathrm{R}$ and $\mathrm{pH}$ value was remarkable $(\mathrm{p}<0.05)$; after the correlation analysis by SPSS,

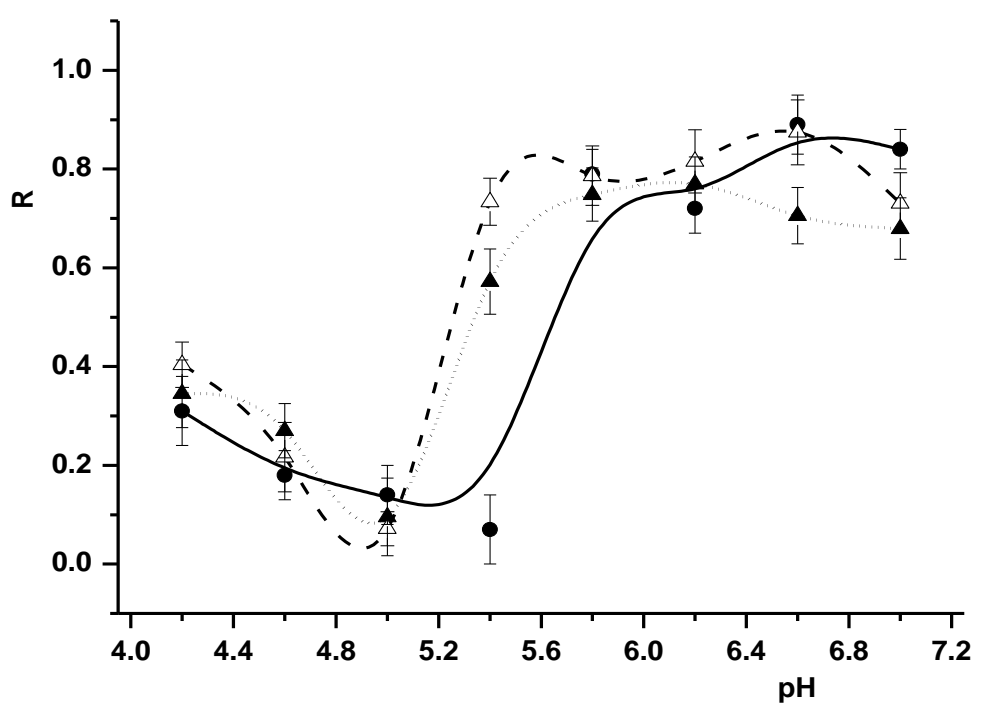

Figure 3. Stability coefficient of milk samples as a function of $\mathrm{pH}$. $\mathrm{R}$ is the ratio of absorbance before and after samples centrifugated, which was determined by a ultraviolet spectrophotometer (UV-1601 ultraviolet spectrophotometer, Shimadzu), at $780 \mathrm{~nm}$. •, Murrah; $\Delta$, $\mathrm{F}_{1} ; \boldsymbol{\Delta}, \mathrm{F}_{\mathrm{H}}$. The data presented are averages of three replications with the error bars indicating the standard deviation. 


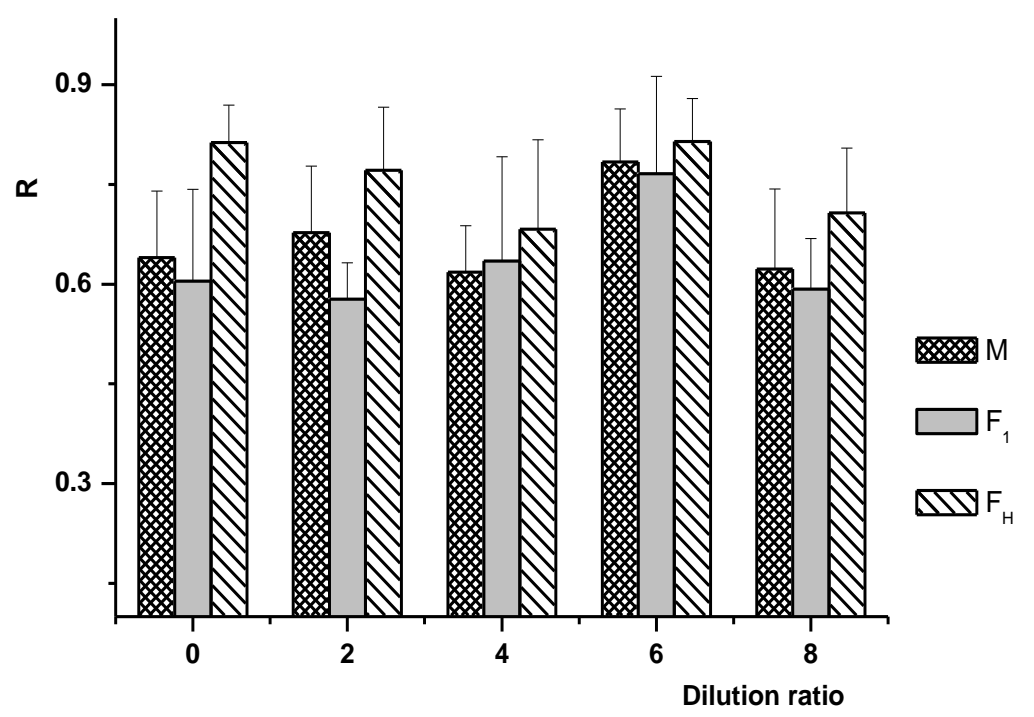

Figure 4. Stability coefficient of milk samples as a function of dilution ratio. $\mathrm{R}$ is the ratio of absorbance before and after samples centrifugated, which was determined by a ultraviolet spectrophotometer (UV-1601 ultraviolet spectrophotometer, Shimadzu), at $780 \mathrm{~nm}$. M, Murrah. Results are the average of three repeated measurements with the error bars indicating the standard deviation.

the correlation coefficients between $\mathrm{R}$ and $\mathrm{pH}$ were 0.815 , 0.772 , and 0.751 for Murrah, $\mathrm{F}_{\mathrm{H}}$, and $\mathrm{F}_{1}$ milk, respectively $(\mathrm{p}<0.05)$. However, the correlation between milk concentration and $R$ was not significant ( $p>0.05$, data not shown).

\section{Effect of temperature and concentration of three cattle breeds on milk viscosity}

There are few researches focused on the milk viscosity of different cattle breeds. Jeurnink and Kruif found that heating temperature, holding time, and $\beta$-lactoglobulin influenced the viscosity of bovine skim milk (Jeurnink ansd Kruif, 1993). Milk viscosities of three cattle breeds were presented in Figure 5 and 6. All milk viscosities were significantly $(\mathrm{p}<0.01)$ affected by temperature (Figure 5) and concentration (Figure 6). The correlation coefficients between viscosity and temperature analyzed by correlation analysis were $-0.902,-0.858$, and -0.854 , and those between viscosity and concentration were $-0.897,-0.894$, and -0.877 , for Murrah, $F_{H}$, and $F_{1}$, respectively. Figure 4 shows that milk viscosity decreased with the increasing temperature. The milk viscosity in all breeds sharply decreased from $4^{\circ} \mathrm{C}$ to $65^{\circ} \mathrm{C}$. Meanwhile, it is easy to find that the viscosity of hybrid offspring milk was higher than that of river buffalo (Murrah) milk, and $F_{1}$ was higher than $F_{H}$ (Figure 5). The average viscosity of hybrid offspring was $0.29 \mathrm{mPa}$.s, above that of Murrah milk. The viscosity slowly decreased from 60 to $95^{\circ} \mathrm{C}$, and it showed no significant differences among

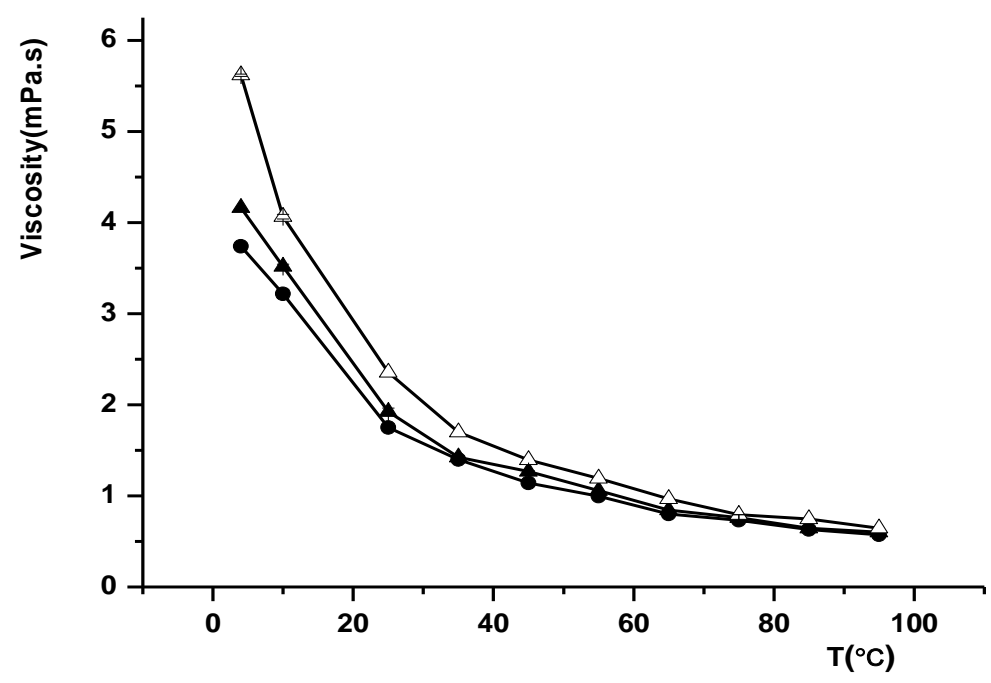

Figure 5. Viscosity of milk samples (measured using a Ostwald capillary viscometer) as a function of temperature. Symbols: •, Murrah; $\Delta, \mathrm{F}_{1} ; \boldsymbol{\Delta}, \mathrm{F}_{\mathrm{H}}$. Results are the average of three repeated measurements with the error bars indicating the standard deviation. 


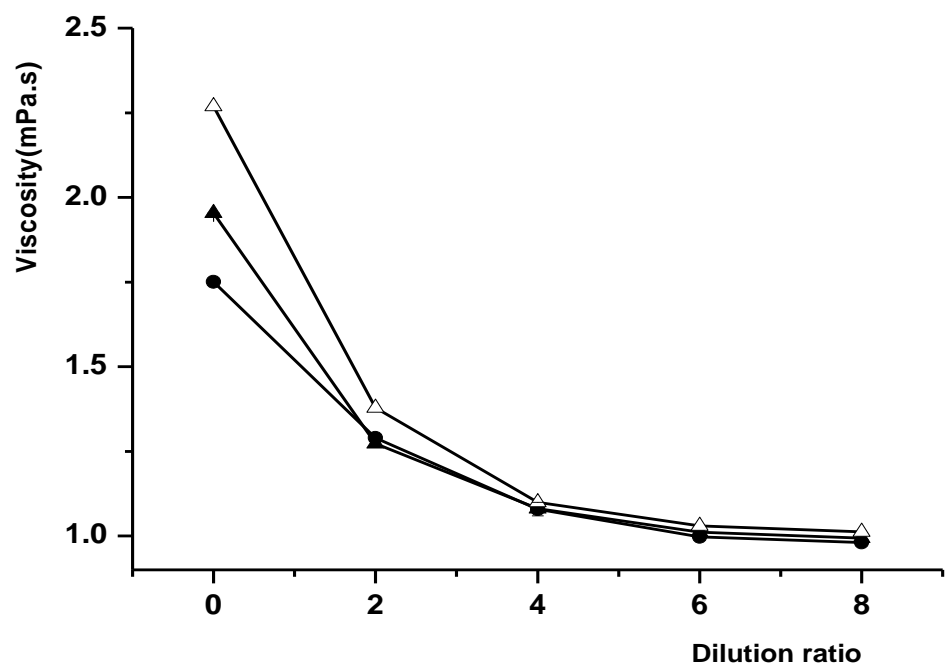

Figure 6. Viscosity of milk samples (measured using a Ostwald capillary viscometer) as a function of dilution ratio. Symbols: Murrah; $\Delta, \mathrm{F}_{1} ; \boldsymbol{\Delta}, \mathrm{F}_{\mathrm{H}}$. Results are the average of three repeated measurements with the error bars indicating the standard deviation.

all breeds (Figure 5). This was attributed to the denaturation of whey protein adhered to the casein micelles and the reduction in frictional resistance and surface area (Jeurnink and Kruif, 1993; Kristensen et al., 1997). The differences in viscosity among different breeds presented a good consistency with the milk composition (Table 1).

The viscosity of all milks showed the same trend of reduction with the decreasing milk concentration as follows: $F_{1}>F_{H}>$ Murrah (Figure 6). There were significant differences $(\mathrm{p}<0.05)$ in viscosity among the three breeds at high concentrations ( $25 \%$ to $100 \%$ ); the viscosity of $\mathrm{F}_{1}$ was significantly $(\mathrm{p}<0.05)$ higher than that of $\mathrm{F}_{\mathrm{H}}$, whereas only slight differences were observed in low concentrations $(12.5 \%$ to $25 \%)$.

\section{Effect of $\mathrm{pH}$ and concentration of three cattle breeds on milk zeta potential}

Zeta potential has been widely used to assay the magnitude of charge content on colloidal particles and evaluate the stability of colloidal dispersion (Anema and Klostermeyer, 1996; Morrison and Ross, 2002; Duan et al., 2011). Zeta potentials of milk samples were significantly $(\mathrm{p}<0.05)$ affected by $\mathrm{pH}$ value (Figure 7$)$. The correlation coefficients between Zeta potentials and $\mathrm{pH}$ value analyzed by correlation analysis were $-0.995,-0.972$, and -0.986 for Murrah, $F_{H}$, and $F_{1}$, respectively. It indicated that milk zeta potentials were evidently affected by varying $\mathrm{pH}$, as clearly represented by river buffalo milk.

Figure 7 shows that the absolute value of zeta potential of the three local kinds of buffalo milk decreased linearly

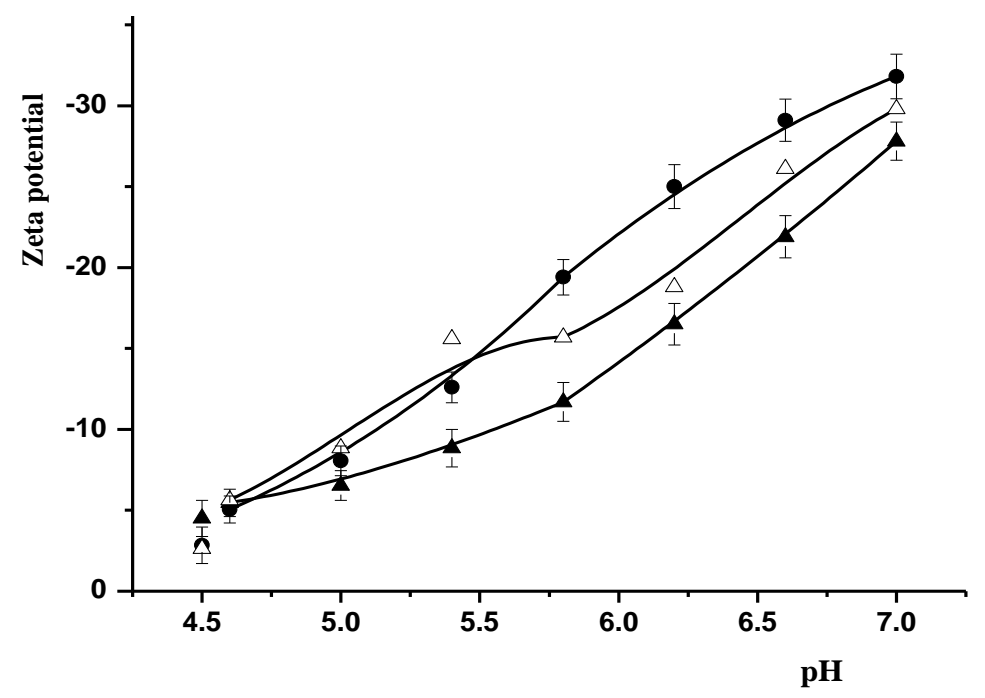

Figure 7. Zeta potential of milk samples as a function of $\mathrm{pH}$. Whole samples were conducted by laser Doppler electrophoresis with the Nano-S Zetasizer (Malvern Instruments Limited, Malvern, Worcestershire, UK) after diluted 200 times with Milli Q-water. Symbols: Murrah; $\Delta, \mathrm{F}_{1} ; \boldsymbol{\Delta}, \mathrm{F}_{\mathrm{H}}$. The data presented are averages of three replications with the error bars indicating the standard deviation. 


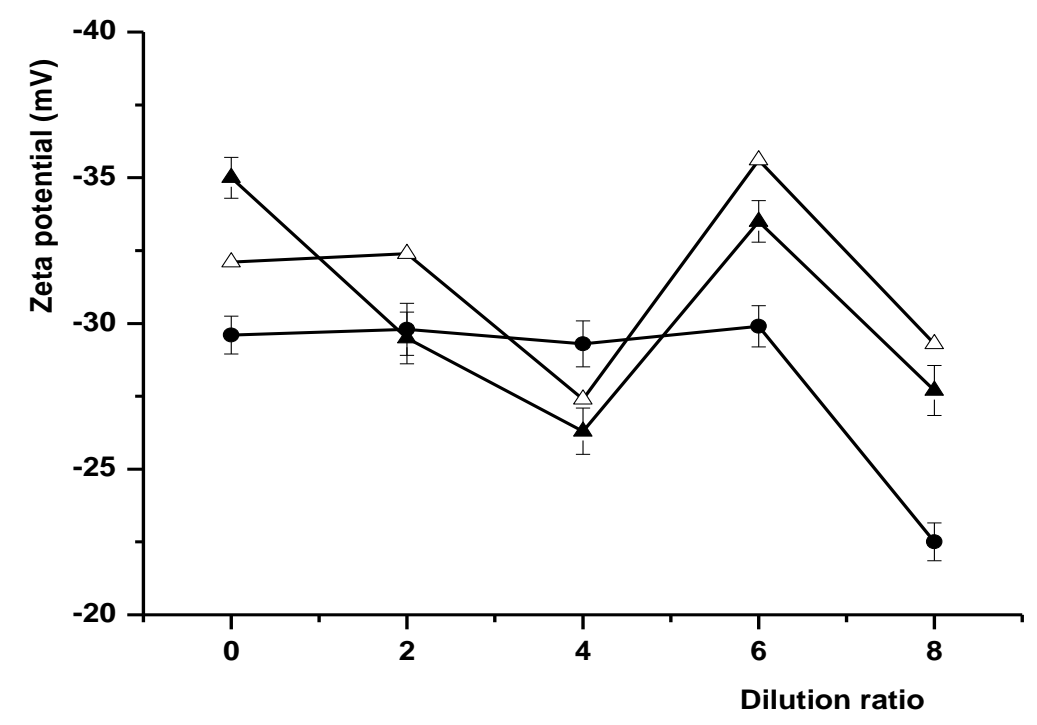

Figure 8. Zeta Potential of milk samples as a function of dilution ratio. Whole samples were conducted by laser Doppler electrophoresis with the Nano-S Zetasizer (Malvern Instruments Limited, Malvern, Worcestershire, UK) after diluted 200 times with Milli Q-water. Symbols: $\bullet$, Murrah; $\Delta, \mathrm{F}_{1} ; \boldsymbol{\Delta}, \mathrm{F}_{\mathrm{H}}$. Results are the average of three repeated measurements with the error bars indicating the standard deviation.

with the reducing $\mathrm{pH}$ (from 7.0 to 4.5 ). Figure 7 shows that the absolute zeta potential of milk suspension of Murrah was remarkably $(p<0.05)$ higher than that of $F_{H}$. It is noteworthy that the average absolute zeta potential of Murrah milk was $6.85 \mathrm{mV}$ above that of $\mathrm{F}_{\mathrm{H}}$ and $3.73 \mathrm{mV}$ higher than that of $\mathrm{F}_{1}$ at $\mathrm{pH} 5.8$ to 7.0. However, the absolute zeta potential of $F_{1}$ milk suspension was slightly higher than that of Murrah at $\mathrm{pH} 4.6$ to 5.6.

Zeta potentials of all milk samples as a function of dilution ratio are shown in Figure 8. The absolute value of zeta potential of the three local kinds of buffalo milk decreased with the reducing concentration in the initial stage, then increased, but finally decreased. The absolute value of zeta potential of all the samples reached the maximum while the milk were diluted 6 times. Meanwhile, it also can be seen that the absolute value of zeta potentials of the three local kinds of buffalo milk were different, and $\mathrm{F}_{1}$ was higher than $\mathrm{F}_{\mathrm{H}}$, followed by Murrah (Figure 8). It indicated that the three local kinds of buffalo milk dispersion system was much more stable when they were diluted at 6 times, and $F_{1}$ was the most stable dispersion system. This may relate to the different dry matter content and the casein micelles distribution.

With the reducing $\mathrm{pH}$, surface charge of colloidal particles increased, which enhanced the intermolecular electrostatic repulsion among proteins and resulted in more stable state. Some works have been done in this area. Bouzid et al. (2008) found that the zeta potential of skim bovine milk varies linearly with the $\mathrm{pH}$, from -4 to $-24 \mathrm{mV}$ between $\mathrm{pH} 5.0$ and 6.7, respectively. After that, observations on zeta potential of the Mediterranean buffalo milk fat globules and Switzerland cow milk fat globules under the native $\mathrm{pH}$ were also reported (Ménard et al., 2010). This work has demonstrated that the dispersion stability of river buffalo milk was superior to that of hybrid offspring milk, which may be related to the higher Ts content in $F_{1}$ milk. Increasing particle size contributes to the aggregation of casein with denatured whey protein and the interaction between casein micelles and whey protein under reduced pH (Klein et al., 2010; Kehoe and Foegeding, 2011). Other milk compositions could be contributors too, such as bovine lactoferrin, fat globule membrane, etc. Bengoechea et al. (Bengoechea et al., 2011) used zeta potential changes to reveal the changes of conformation, aggregation, and electrical charge of bovine lactoferrin. Michalski suggested that a significant increase in zeta potential indicated the incorporation of caseins into the milk fat globule membrane (Michalski et al., 2006).

Zeta potential in the present study did not reach zero at the isoelectric point as described (Bouzid et al., 2008), but it was in accordance with the results of Anema and Klostermeyer (1996). These results can be attributed to the influence of ionic strength on the electrostatic interactions in the system, and the electrostatic repulsion between individual proteins was reportedly reduced (Bengoechea et al., 2011).

\section{Casein of milks from three cattle varieties}

Proteins of three types of milk were detected by SDSPAGE (Figure 9). Buffalo $\alpha_{\mathrm{s}}$-casein had a slightly faster mobility than standard $\alpha_{s}$-casein and seemed to be lack of one kind of $\alpha_{\mathrm{s}}$-casein, which is worth of further investigations. Buffalo $\beta$-casein had a slightly slower mobility than standard $\beta$-casein. There is no significant 


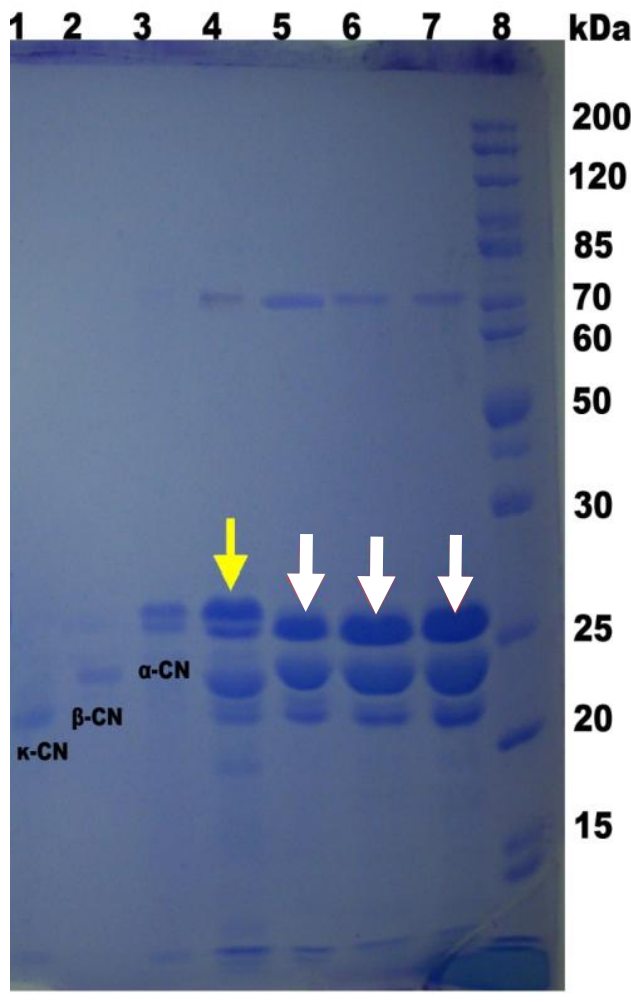

Figure 9. SDS-PAGE of milk protein samples. Electrophoresis was carried out with a vertical electrophoresis system and on $12 \%$ acrylamide separating gel and 4\% stacking gel with the help of standard mixtures of marker proteins. Lane 1: standard of $\kappa$-casein $(\kappa-\mathrm{CN})$, Lane 2: standard of $\beta$-casein $(\beta-\mathrm{CN})$, Lane 3: standard of $\alpha$-casein $(\alpha-\mathrm{CN})$, Lane 4: Holstein milk as a reference, Lane 5: Murrah milk, Lane 6: $\mathrm{F}_{\mathrm{H}}$ milk, Lane 7: $\mathrm{F}_{1}$ milk, Lane 8: molecular weight markers 10 to $200 \mathrm{kDa}$ (Fermentas-\#SM0661).

difference between buffalo caseins. It indicated that milk protein and molecular weight was greatly related to cattle breeds. Nevertheless, the differences between the caseins of hybrid offspring and their male parent could be ignored. $\alpha_{s 1}$-casein is the major allergen (Elsayed et al., 2004), further study on which is helpful to the development of hypoallergenic or non-allergic dairy products from Chinese buffalo milk.

\section{CONCLUSION}

By comparing the three cattle breeds for bovine milk composition and physicochemical properties, this work demonstrated that the breeds had evident effect on milk composition and physicochemical properties. Overall, the nutritional value of river buffalo milk was lower than that of swamp buffalo and their hybrid offspring. However, the milk of crossbreed multi-generation was more like that of their paternal strain, and its nutritional value was lower than that of $\mathrm{F}_{1}$, so were the physicochemical properties. There were no clear differences in milk protein molecular weight between Murrah, $F_{1}$, and $F_{H}$. Comparing with river buffalo milk, the technological characteristics of hybrid offspring buffalo $\left(\mathrm{F}_{\mathrm{H}}\right)$ milk are conducive for further utilization of their nutritional value. This work provides a reference to improve buffalo varieties for milk production and to produce different types of dairy products from different types of milk, which warrants further studies.

\section{ACKNOWLEDGEMENTS}

The work was supported by the National Natural Science Foundation of China (Grant No. 31071576) and Talents Project of Guangxi University (Grant No. XZL090325), P. R. China.

\section{REFERENCES}

Ahmad, S., I. Gaucher, F. Rousseau, E. Beaucher, M. Piot, J. Grongnet and F. Gaucheron. 2008. Effects of acidification on physico-chemical characteristics of buffalo milk: A comparison with cow's milk. Food Chem. 106:11-17.

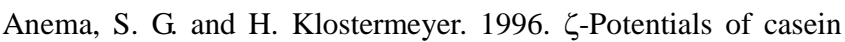
micelles from reconstituted skim milk heated at $120^{\circ} \mathrm{C}$. Int. Dairy J. 6:673-687.

Bengoechea, C., I. Peinado and D. J. McClements. 2011. Formation of protein nanoparticles by controlled heat treatment of lactoferrin: factors affecting particle characteristics. Food Hydrocoll. 25:1354-1360.

Benincasa, C., J. Lewis, G. Sindona and A. Tagarelli. 2008. The use of multi element profiling to differentiate between cow and buffalo milk. Food Chem. 110:257-262.

Bouzid, H., M. Rabiller-Baudry, L. Paugam, F. Rousseau, Z. Derriche and N. E. Bettahar. 2008. Impact of zeta potential and size of caseins as precursors of fouling deposit on limiting and critical fluxes in spiral ultrafiltration of modified skim milks. J. Memb. Sci. 314:67-75.

Duan, R. L., X. Sun, J. Liu, T. Gong and Z. R. Zhang. 2011. Mixed micelles loaded with silybin-polyene phosphatidylcholine complex improve drug solubility. Acta Pharmacol. Sin. 32: $108-115$

Elsayed, S., D. J. Hilly and T. V. Do. 2004. Evaluation of the allergenicity and antigenicity of bovine-milk as1-casein using extensively purified synthetic peptides. Scand J. Immunol. 60: 486-493.

FAO. 2010. Bulletiin of the international dairy federation. The world dairy situation Bulletin No.446/2010.

Han, B. Z., Y. Meng, M. Li, Y. X. Yang, F. Z. Ren, Q. K. Zeng, and M. J. R. Nout. 2007. A survey on the microbiological and chemical composition of buffalo milk in China. Food Control 18:742-746.

Han, G. and Q. Ding. 1994. A study on physicochemical properties of Chinese buffaloo milk. J. South China Agr Univ. 15:92-97. (in Chinese)

Jeurnink, T. J. M. and K. G. D. Kruif. 1993. Changes in milk on heating: viscosity measurements. J. Dairy Res. 60:139-150.

Kehoe, J. J. and E. A. Foegeding. 2011. Interaction between $\beta$ casein and whey proteins as a function of $\mathrm{pH}$ and salt concentration. J. Agric. Food. Chem. 59:349-355. 
Klein, M., A. Aserin, P. Ben Ishai and N. Garti. 2010. Interactions between whey protein isolate and gum Arabic. Colloids Surf., B. Biointerfaces 79:377-383.

Kristensen, D., P. Y. Jensen, F. Madsen and K. S. Birdi. 1997. Rheology and surface tension of selected processed dairy fluids influence of temperature. J. Dairy Sci. 80:2282-2290.

Laemmli, U. K. 1970. Cleavage of structural proteins during the assembly of the head of the head of bacteriophage T4. Nature 227:680-685.

Lindmark-Månsson, H., R. Fondén and H. E. Pettersson. 2003. Composition of Swedish dairy milk. Int. Dairy J. 13:409-425.

Liu, C., Z. Teng, Q. Y. Lu, R. Y. Zhao, X. Q. Yang, C. H. Tang and J. M. Liao. 2011. Aggregation kinetics and $\zeta$-potential of soy protein during fractionation. Food Res. Int. 44:1392-1400.

Ménard, O., S. Ahmad, F. Rousseau, V. Briard-Bion, F. Gaucheron and C. Lopez. 2010. Buffalo vs. cow milk fat globules: Size distribution, zeta-potential, compositions in total fatty acids and in polar lipids from the milk fat globule membrane. Food Chem. 120:544-551.

Maurice-Van Eijndhoven, M. H. T., S. J. Hiemstra and M. P. Calus. 2011. Short communication: milk fat composition of 4 cattle breeds in the Netherlands. J. Dairy Sci. 94:1021-1025.

McMahon, D. J., H. Du, W. R. McManus and K. M. Larsen. 2009. Microstructural changes in casein supramolecules during acidification of skim milk. J. Dairy Sci. 92:5854-5867.

McMahon, D. J. and B. S. Oommen. 2008. Supramolecular structure of the casein micelle. J. Dairy Sci. 91:1709-1721.

Michalski, M. C., N. Leconte, V. Briard-Bion, J. Fauquant, J. L. Maubois and H. Goude'dranche. 2006. Microfiltration of raw whole milk to select fractions with different fat globule size distributions: process optimization and analysis. J. Dairy Sci. 89:3778-3790.
Morrison, I. D. and S. Ross. 2002. Colloidal dispersions: suspensions, emulsions, and foams. Wiley, New York, USA.

Norrapoke, T., M. Wanapat and S. Wanapat. 2012. Effects of protein level and mangosteen peel pellets (mago-pel) in concentrate diets on rumen fermentation and milk production in lactating dairy crossbreds. Asian Australas. J. Anim. Sci. 25: 971-979.

Pang, K., Q. K. Zeng, Q. Zheng, M. Y. Li, B. X. Shi and F. Z. Ren. 2007. Study on changes of chemical compositions in Murrah $\times$ Xilin buffalo milk. Food Sci. 28:44-48. (in Chinese).

Poulsen, N. A., F. Gustavsson, M. Glantz, M. Paulsson, L. B. Larsen and M. K. Larsen. 2012. The influence of feed and herd on fatty acid composition in 3 dairy breeds (Danish Holstein, Danish Jersey, and Swedish Red). J. Dairy Sci. 95:6362-6371.

Salaün, F., B. Mietton and F. Gaucheron. 2005. Buffering capacity of dairy products. Int. Dairy J. 15:95-109.

Slyke, D. D. V. 1922. On the measurement of buffer values and on the relationship of buffer value to the dissociation constant and reaction of the buffer solution. J. Biol. Chem. 52:525-570.

Terramoccia, S., A. Bartocci, S. D. Giovanni and S. Bartocci. 2012. The influence of dietary characteristics on the milk quantity and quality of riverine buffaloes: Estimate of the energy/protein requirements, for a medium-high production, in the first ninety days of lactation. Asian Australas. J. Anim. Sci. 25:335-340.

Waritthitham, A., C. Lambertz, H. J. Langholz, M. Wicke and M. Gauly. 2010. Assessment of beef production from Brahman $\times$ Thai native and Charolais $\times$ Thai native crossbred bulls slaughtered at different weights. I: Growth performance and carcass quality. Meat Sci. 85:191-195.

Xie, X., Q. Meng, Z. Cui and L. Ren. 2012. Effect of cattle breed on meat quality, muscle fiber characteristics, lipid oxidation and fatty acids in China. Asian Australas. J. Anim. Sci. 25:824831. 